\title{
EFEKTIVITAS RANGE OF MOTION (ROM) AKTIF TERHADAP KEKUATAN OTOT EKSTREMITAS ATAS DAN EKSTREMITAS BAWAH PADA LANSIA
}

\author{
EFFECTIVENESS OF RANGE OF MOTION (ROM) ACTIVE ON MUSCLE \\ STRENGTH THE EXTREMITY AND THE UNDER EXTREMITY IN ELDERLY
}

\author{
Siti Hartinah*, Lilik Pranata, Dheni Koerniawan \\ Fakultas Ilmu Kesehatan, Universitas Katolik Musi Charitas Palembang \\ *Korespondensi Penulis, email : lilikpranataukmc@gmail.com
}

\begin{abstract}
Elderly experienced the physiologic and morphologic changes in musculoskeletal system especially muscular which are decreasing muscle strength and mass.To analyze effectivity active ROM to upper and lower extremities muscle strength for elderly in Panti Tresna Werdha Teratai KM. 6 Palembang.This study used quasy experiment design with pre-post test nonequivalent control group approach to 18 respondents with total sampling. Active ROM done for three times in a week with duration 30 minutes and three times repetition in every extremity. Friedman and Mann-Whitney used for bivariate analysis. Majority in intervention group had 4 and 5 muscle strength scale and control group had and 4 muscle strength scale. Friedman test showed significant difference in upper $(p=0.001)$ and lower extremities $(p=0.008)$. Mann-Whitney test showed significant difference in upper extremities $(p=0.03)$ after active ROM intervention, but not significant in lower extremities $(p=0.058)$. Elderly and Panti Tresna Werdha Teratai KM. 6 Palembang expected can do the active ROM exercise and progaming it for daily routine because this exercise proven can improve the muscle strength.

Keywords: active ROM excercise, muscle strength, upper limb, lower limb, elderly
\end{abstract}

\begin{abstract}
ABSTRAK
Lansia mengalami perubahan fisiologis dan morfologis pada system muskuloskeletal khususnya otot yaitu adanya penurunan kekuatan otot dan massa otot. Mengetahui analisis efektifitas ROM aktif terhadap kekuatan otot ekstremitas atas dan ekstremitas bawah pada lansia di Panti Tresna Werdha Teratai KM. 6 Palembang.Penelitian ini menggunakan desain Quasy Experiment dengan pendekatan Pre-Post Test Non Equivalent Control Grup terhadap 18 responden dengan teknik total sampling. ROM aktif dilakukan 3 kali dalam seminggu dengan durasi 30 menit dan diulang sebanyak 3 kali pada tiap ekstremitas. Friedman dan Mann-Whitney digunakan untuk analis bivariat.Mayoritas dalam kelompok intervensi memiliki skala kekuatan otot 4 dan 5 dan kelompok kontrol memiliki skala kekuatan otot 4.Uji Friedman menunjukkan perbedaan yang signifikan pada ekstremitas atas $(p=0,001)$ dan ekstremitas bawah $(p=0,008)$. Uji Mann-Whitney menunjukkan perbedaan yang signifikan pada ekstremitas atas $(p=0,03)$ setelah intervensi ROM aktif, tetapi tidak signifikan pada ekstremitas bawah $(p=0,058)$. Lansia dan Panti Tresna Werdha Teratai diharapkan dapat melakukan latihan $R O M$ aktif dan memprogramkan secara rutin karena latihan ini terbukti dapat meningkatkan kekuatan otot.

Kata kunci: $R O M$ aktif, kekuatan otot, ekstremitas atas, ekstremitas bawah, lansia
\end{abstract}




\section{PENDAHULUAN}

Proses menua merupakan suatu proses yang akan terjadi disepanjang hidup manusia yang dimulai sejak permulaan kehidupan."Menjadi tua" adalah suatu keadaan dan masa yang pastiterjadi didalam kehidupan manusia, (Padila 2013). Menua bukanlah suatu penyakit tetapi merupakan proses berkurangnya daya tahan tubuh dalam menghadapi rangsangan dari dalam maupun dari luar tubuh (Muhith, A. \& Siyoto 2016), Sedangkan Menurut Peraturan Menteri Kesehatan RI Nomor 25 Tahun 2016 Tentang Rencana Aksi Nasional Kesehatan Lanjut Usia, yang dimaksud denganlanjut usia ialah seseorang yang telah mencapai usia 60 tahun keatas (Kemenkes RI 2017) Populasi lanjut usia di seluruh dunia diperkirakan ada sekitar 500 juta jiwa dengan usia rata-rata 60 tahun dan diperkirakan pada tahun 2025 meningkat mencapai 1,2 milyar jiwa (Padila, 2013). Penduduklansia di Indonesia menduduki peringkat ke -4 yang terbesar di dunia setelah Cina, India dan Amerika Serikat (Muhith, A. \& Siyoto 2016) Penduduk lansia di Indonesia tahun 2017 mencapai 23,66 juta jiwa dan diprediksi pada tahun 2020 akan meningkat menjadi 27,08 juta jiwa (Kemenkes RI 2017), Menurut Profil Kesehatan Posyandu Lansia di Kabupaten Tuban Tahun 2010 dalam Safa'ah (2013) menunjukkan bahwa penyakit otot dan jaringan sebanyak 57.314 kasus $(29,8 \%)$ dan menduduki peringkat pertama diantara penyakit-penyakit lainnya. Lansia mengalami perubahan fisiologis dan morfologis salah satunya pada sistem muskuloskeletal khususnya otot. Pada perubahan fisiologis yang terjadi adalah penurunan kekuatan otot dan penurunan massa otot (Padila 2013). Penurunan kekuatan otot dapat menimbulkan penurunan kemampuan fungsional pada lansia karena kekuatan otot mempengaruhi hampir semua aktivitas sehari-hari sehingga kebutuhan hidupnya dapat meningkat dan adanya ketergantungan untuk mendapat bantuan dari orang lain (Muhith, A. \& Siyoto 2016) Penurunan kekuatan otot pada ektremitas atas dapat menyebabkan lansia tidak dapat memegang cangkir atau gelas dengan baik, tidak dapat memegang dan mengangkat barang yang berat sedangkan penurunan kekuatan otot pada ektremitas bawah dapat mengakibatkan gerakan menjadi lamban dan kaku, langkah menjadi pendekpendek, kaki tidak dapat menapak dengan kuat, mudah goyah, serta berdiripun sudah tidak stabil yang dapat menimbulkan resiko mudah jatuh (Santoso, H. \& Ismail 2009). Latihan fisik yang sering dilakukan oleh lansia, yaitu latihan rentang gerak, logoterapi, senam ergonomik, senam low back pain, dan senam yoga (Padila 2013). Hasil penelitian menunjukkan terdapat hubungan yang signifikan pada seluruh sendi baik di ekstremitas atas dan bawah (p: 0,01). ROM sangat bermanfaat untuk membatu lansia yang mengalami kekakuan sendi. Tetapi bentuk latihan yang dianjurkan bagi lansia yaitu latihan range of motion (ROM), karena latihan ROM ini aman dan efektif bagi lansia (Kisner, C. \& Colby 2016). Menurut Potter \& Perry dalam Mulyanti (2015) ROM adalah latihan yang dilakukan untuk mempertahankan atau memperbaiki tingkat kesempurnaan kemampuan menggerakkan persendian secara normal dan untuk meningkatkan massa otot dan tonus otot. Latihan ROM aktif adalah latihan yang dilakukan sendiri oleh pasien tujuannya adalah menambah atau mempertahankan gerak sendi dan memperkuat otot (Kneale, J. \& Davis 2011). Pada penelitian ini Lansia dilatih untuk mengembalikan fungsi geraknya secara normal, seperti menggerakan $R O M$ bagian bahu, siku, lengan bawah, telapak tangan, jari tangan, lutut, pergelangan kaki dan kaki. Pemberian latihan ROM aktif dilakukan selama satu minggu dengan durasi 30 menit dengan frekuensi maksimal tiga kali pengulangan gerak tujuannya yaitu untuk meningkatkan tingkat kemandirian lansia serta 
meningkatkan kekuatan otot pada lansia (Kisner, C. \& Colby 2016) Perubahan fisiologis yang terjadi pada otot lansia akan mengalami penurunan kekuatan otot dan penurunan massa otot (atropi otot). Kekuatan otot dapat menurun dengan bertambahnya usia seseorang yaitu sebesar 40\% dari usia 30 sampai 80 tahun (Padila 2013). Colombia University Medical Center menemukan bahwa menurunnya kekuatan otot pada lansia terjadi akibat kebocoran kalsium dari kelompok protein dalam sel otot yang disebut ryanodine yang kemudian memicu terjadinya rangkaian kejadian yang membatasi kontraksi serabut otot. Dengan berkurangnya kalsium yang tersedia maka kontraksi otot melemah (Pinontoan, P. M., Marunduh 2015) ROM merupakan serangkaian gerakan yang terjadi pada persendian dari awal sampai akhir pergerakan (Widiarti 2016) Klasifikasi ROM Menurut Kisner (2016) latihan ROM dibedakan menjadi 3 jenis yaitu: ROM aktif, ROM pasif, ROM aktif-Asistif. Latihan $R O M$ aktif merupakan latihan isotonik yang menyebabkan otot berkontraksi. Otot yang dapat berkontraksi maka akan terjadinya perubahan pajang otot dan merangsang aktifitas sel pembentukan otot. Sehingga dengan melakukan latihan $R O M$ ini secara benar dan rutin maka akan meningkatkan tonus otot, massa otot dan kekuatan otot (Ridha, M. R. \& Putri 2015) kekuatan otot adalah gaya yang dihasilkan oleh otot selama kontraksi maksimal Menurut Daniel dan Worthingham's dalam (Mudrikhah 2015) Pengukuran kekuatan otot dapat dilakukan dengan menggunakan pengujian otot secara manual yaitu Manual Muscle Testing (MMT)yaitu:0= tidak ada kontraksi atau gerakan otot sama sekali, 1= terlihat/ teraba kontraksi/ lemah tanpa gerakan, 2= gerakan tanpa melawan graitasi, 3= derakan dengan melawan gravitasi, $4=$ gerakan dengan melawan gravitasi dengan tahanan sedang, 5= gerakan melawan gravitasi dengan tahanan maksimal (Lilik Pranata, Dheni koerniawan 2019).

\section{METODE PENELITIAN}

Penelitian ini dilakukan pada tanggal 14-18 Mei 2018. Metode yang di gunakan dalam penelitian ini adalah kuantitatif dengan desain Quasy Exsperiment dengan pendekatan Pre-Post Test Non-Equivalent Control Group yaitu untuk membandingkan hasil intervensi antara kelompok eksperimen dan kelompok kontrol. Berdasarkan kriteria inklusi dan eksklusi jumlah populasi yang diambil yaitu 22 lansia, 2 orang lansia dari 22 lansia mengatakan sering merasakan kaku dan sesekali muncul rasa nyeri pada persendian kakinya dan 1 lansia mengatakan belum pernah melakukan latihan $R O M$ aktif dan tidak mengetahui tentang latihan $R O M$ aktif. Sehingga sampel dalam penelitian ini adalah 18 lansia. Teknik pengambilan sampel yaitu dengan Teknik total sampling. .Alat ukur yang digunakan untuk mengukur kekuatan otot adalah Manual Muscle Testing $(M M T)$. Penelitian ini menggunakan uji Friedman dan uji Mann-Whitney.

\section{HASIL DAN PEMBAHASAN}

Tabel 1. Distribusi Responden berdasarkan Usia, Jenis Kelamin dan Riwayat Penyakit.

\begin{tabular}{|c|c|c|c|c|c|c|}
\hline \multirow[t]{2}{*}{ Variabel } & \multicolumn{2}{|c|}{$\begin{array}{c}\text { Kelompok } \\
\text { Kontrol }\end{array}$} & \multicolumn{2}{|c|}{$\begin{array}{l}\text { Kelompok } \\
\text { Intervensi }\end{array}$} & \multirow[t]{2}{*}{ Total } & \multirow[t]{2}{*}{$\%$} \\
\hline & $\mathrm{f}$ & $\%$ & $\mathrm{f}$ & $\%$ & & \\
\hline \multicolumn{7}{|l|}{ Usia } \\
\hline Middle Age (45-59) & 1 & $11,1 \%$ & 1 & $11,1 \%$ & 2 & $11,1 \%$ \\
\hline Elderly (60-74) & 3 & $33,3 \%$ & 7 & $77,8 \%$ & 10 & $55.5 \%$ \\
\hline Old $(75-90)$ & 5 & $55,6 \%$ & 1 & $11,1 \%$ & 6 & $33,3 \%$ \\
\hline Jumlah & 9 & $100 \%$ & 9 & $100 \%$ & 18 & $100 \%$ \\
\hline
\end{tabular}




\begin{tabular}{lcccccc}
\hline Jenis Kelamin & 6 & $66,7 \%$ & 5 & $55,6 \%$ & 11 & $61,1 \%$ \\
Laki-laki & 3 & $33,3 \%$ & 4 & $44,4 \%$ & 7 & $38,9 \%$ \\
Perempuan & 9 & $100 \%$ & 9 & $100 \%$ & 18 & $100 \%$ \\
Jumlah & 3 & $33,3 \%$ & 3 & $33,3 \%$ & 6 & $33,3 \%$ \\
\hline Riwayat Penyakit & 1 & $11,1 \%$ & 5 & $55,6 \%$ & 6 & $33,3 \%$ \\
Asam Urat & 1 & $11,1 \%$ & - & - & 1 & $5,6 \%$ \\
Hipertensi & 4 & $44,4 \%$ & 1 & $11,1 \%$ & 5 & $27,8 \%$ \\
Stroke & 9 & $100 \%$ & 9 & $100 \%$ & 18 & $100 \%$ \\
Tidak Ada & & & & & & \\
Jumlah & & &
\end{tabular}

karakteristik responden terbanyak berada pada rentang usia elderly atau 60-74 tahun mayoritas berusia diatas 60-74 tahun. Penelitian ini sejalan dengan teori Kisner \& Colby (2016) seiring bertambahnya usia maka kinerja otot akan berkurang, pada usia 60 dan 70 tahunan berkurangnya kekuatan otot sebesar 15-20\%. Penelitian ini didukung oleh penelitian (Sukis, Syamsulhuda \& Husodo 2016)tentang faktor-faktor yang berhubungan dengan terapi konservatif ROM pada lansia penderita nyeri sendi, Berdasarkan teori dan penelitian terkait yang mendukung, lansia yang mengalami kelemahan otot dengan bertambahnya usia atau usia diatas 60 tahun keatas sehingga usia mempengaruhi kelemahan otot terutama pada elderly atau usia lanjut. Menurut teori (Zhou, Z., Zhenga, L., Wei, D., Ye, M., \& $\mathrm{Li}$ 2013) wanita menopause akan terjadinya perubahan keseimbangan hormonal, hususnya penurunan kadar estrogen dan penurunan aktifitas yang mengakibatkan berkurangnya kekuatan otot dan berkurangnya kepadatan mineral tulang. Karakteristik riwayat penyakit terbanyak menunjukkan, mayoritas responden memiliki riwayat penyakit asam urat dan hipertensi sebanyak 6 lansia $(33,3 \%)$. Hal ini dikarenakan lansia yang mempunyai riwayat penyakit asam urat dan hipertensi kurang untuk melakukan aktifitas fisik karena tidak melakukan aktifitasfisik dalam waktu yang lama dan lebih banyak tirah baring. Penelitian ini sejalan dengan teori (Kowalak 2011) Kurangnya aktifitas fisik dan orang berbaring ditempat tidur akan kehilangan kekuatan otot maupun massa otot secara perlahan dan sekitar $3 \%$ otot akan menghilang perharinya. Massa otot dan kekuatan otot akan menurun pada lanjut usia dan penurunan ini biasanya terjadi karena penyakit. Sehingga riwayat penyakit juga berperan dalam terjadinya penurunan kekuatan otot.

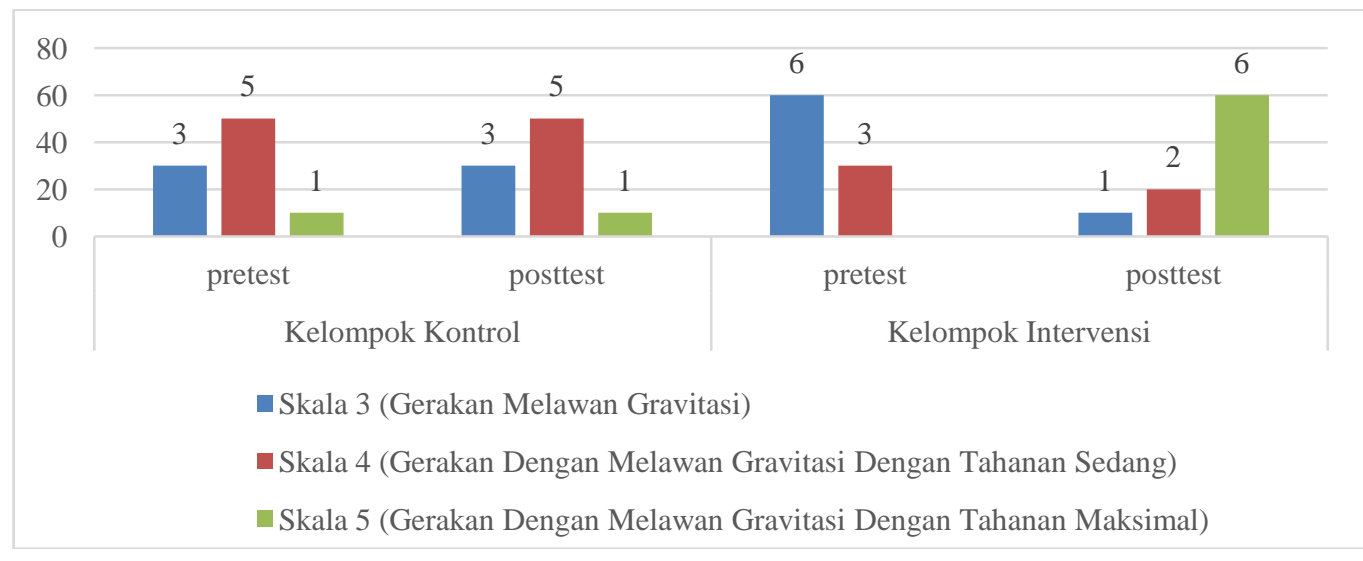

Grafik 1.Grafik Skala Kekuatan Otot Ekstremitas atas Pada Lansia 


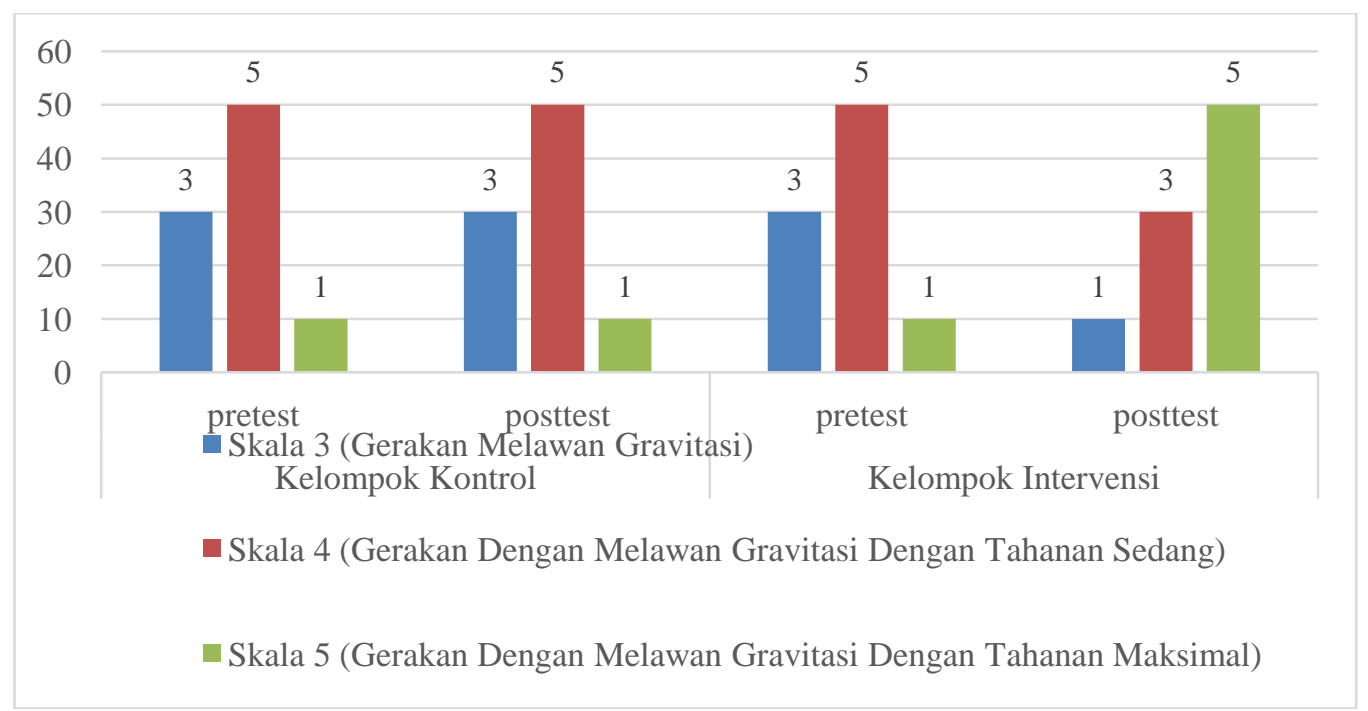

Grafik2.Skala Kekuatan Otot Ekstremitas Bawah Pada Lansia

Hasil penelitian juga menunjukkan bahwa skala kekuatan otot ekstremitas atas kelompok intervensi pada pengukuran pretest (sebelum dilakukan latihan $R O M$ aktif) yaitu, sebanyak 6 responden $(66,7 \%)$ memiliki nilai skala kekuatan otot 3,3 responden $(33,3 \%)$ memiliki nilai skala kekuatan otot 6 responden $(66.7 \%)$ memiliki nilai skala kekuatan otot 5 . Hasil penelitian juga menunjukkan bahwa skala kekuatan otot ekstremitas bawah kelompok intervensi pada pengukuran pretest 5 responden $(55,6 \%)$ memiliki sedangkan hasil observasi setelah diberikan latihan ROM aktif (posttest) selama 3 kali, 5 responden $(55,6 \%)$ memiliki nilai skala kekuatan otot 5. Penelitian ini juga didukung oleh teori (Kneale, J. \& Davis 2011), mengungkapkan bahwa mekanisme kontraksi otot dapat menimbulkan rangsangan melalui neuromuskular yang akan memberikan rangsangan ke serabut otot terutama sistem saraf pusat yang merangsang dalam memproduksi asetilkolin sehingga serabut otot dapat berkontraksi. Penelitian ini didukung oleh penelitian (Andriani, H., Indriati 2013), tentang pengaruh $R O M$ aktif terhadap kekuatan otot ekstremitas atas pada lansia. Hasil penelitian menunjukkan bahwa terdapat perbedaan kekuatan otot ekstremitas atas sebelum dan sesudah dilatih ROM $(p=0,008)$. Hasil penelitian menunjukkan bahwa skala kekuatan otot ekstremitas atas dan ekstremitas bawah pada kelompok kontrol antara pengukuran pretest memiliki nilai skala kekuatan otot yang sama yaitu 5 responden $(55.6 \%)$ memiliki nilai skala kekuatan otot 4 , sedangkan hasil observasi setelah hari ke tiga dengan pengukuran posttest skala kekuatan otot ekstremitas atas dan ekstremitas bawah pada kelompok kontrol masih sama dan tetap. Teori (Kisner, C. \& Colby 2016), mengungkapkan bahwa kurangnya aktivitas fisik dan imobilisasi akan mengalami terjadinya penurunan kekuatan otot $8 \%$ setiap minggunya

Tabel 2. Perbedaan Pengukuran Kekuatan Otot Ekstremitas Atas dan Ekstremitas Bawah dengan Menggunakan Uji Friedman

\begin{tabular}{lcc}
\hline Kelompok & Mean Rank & p value \\
\hline Intervensi & & \\
Ekstremitas atas & & \\
\hline
\end{tabular}




\begin{tabular}{llc}
\hline Pretest & 1,78 & 0,000 \\
Posttest 1 & 1,78 & \\
Posttest 2 & 3,00 & \\
Posttest 3 & 3,44 & 0,008 \\
\hline Ekstremitas Bawah & & \\
\hline Pretest & 2,00 & \\
Posttest 1 & 2,00 & \\
Posttest 2 & 2,72 & - \\
Posttest 3 & 3,28 & \\
\hline Kontrol & & \\
Ekstremitas atas & & - \\
\hline Pretest & 2,50 & \\
Posttest 1 & 2,50 & \\
Posttest 2 & 2,50 & \\
Posttest 3 & 2,50 & \\
\hline Ekstremitas Bawah & & \\
\hline Pretest & 2,50 & \\
Posttest 1 & 2,50 & \\
Posttest 2 & 2,50 & \\
Posttest 3 & 2,50 & \\
\hline
\end{tabular}

Hasil tabel 2 menunjukkan uji beda yang dilakukan pada penelitian ini dengan menggunakan uji Friedman memberikan hasil adanya perbedaan skala kekuatan otot ekstremitas atas yang signifikan antara pengukuran pretest, posttest 1 , posttest 2 dan posttest 3 kelompok intervesi $(p=0,001)$, sedangkan pada ekstremitas bawah memberikan hasil adanya perbedaan skala kekuatan otot ekstremitas bawah yang signifikan antara pengukuran pretest, posttest 1 , posttest 2 dan posttest 3 $(p=0,008)$. Skala kekuatan otot ekstremitas atas dan ekstremitas bawah pada penelitian ini terjadi disebabkan karena adanya perubahan anatomis, yaitu peningkatan jumlah miofibril, peningkatan ukuran miofibril, peningkatan jumlah total protein kontraktil khususnya kontraktil myosin (Hardika \& Pranata 2019). Selain itu, otot juga disebabkan perubahan biokimia otot, yaitu peningkatan konsentrasi kreatin, fosfat, ATP dan glikogen. Proses kontraksi otot ini diawali dengan datangnya impuls saraf yang mengenai bagian sinaps serabut otot yang dipenuhi dengan asetilkolin. Asetil kolin inilah yang nantinya akan menyerap ion kalsium keserabut otot, setelah itu akan membentuk miosin dan filamen tipis kemudian membentuk energi dan dilepaskan kearah filamen tipis hingga membuat filament tipis menjadi berkerut, dari sinilah yang menyebabkan terjadinya otot dapat kontraksi (Kirnanoro 2017).

Hasil penelitian ini membuktikan bahwa latihan $R O M$ aktif selama tiga kali seminggu dengan durasi waktu \pm 30 menit, akan meningkatkan skala kekuatan otot ekstremitas atas dan ekstremitas bawah. Penelitian ini juga sejalan dengan penelitian (Imron, J. \& Asih 2015) tentang pengaruh latihan ROM aktif terhadap keaktifan fisik pada lansia, yang menunjukkan bahwa terdapat pengaruh latihan $R O M$ aktif terhadap keaktifan fisik dan kekuatn otot pada lansia setelah diberikan latihan $R O M$ aktif selama tiga kali dalam seminggu. Penelitian ini sejalan dengan teori (Kneale, J. \& Davis 2011), teori ini mengungkapkan bahwa latihan ROM aktif adalah latihan yang dilakukan secara mandiri untuk mempertahankan gerakkan sendi dan untuk meningkatkan massa otot dan tonus otot. Hasil analisis uji Friedman di kelompok kontrol menunjukkan bahwa Perbedaan tidak 
signifikan antara skala kekuatan otot ekstremitas atas dan ekstremitas bawah pada pengukuran pretest, posttest 1 , posttest 2 dan posttest 3 dengan rata-rata skala kekuatan otot 2,50 (Lilik Pranata, Dheni koerniawan 2019a). Hal ini disebabkan karena kelompok kontrol tidak mendapatkan latihan $R O M$ aktif sehingga tidak mendapatkan kontraksi otot dan perubahan sel pembentuk otot sehingga nilai skala kekuatan otot ekstremitas atas dan ekstremitas bawah sama dan tidak mendapatkan perubahan.

Tabel 3. Perbedaan Pengukuran Kekuatan Otot Ekstremitas Atas dan Ekstremitas Bawah pada Lansia setelah diberikan ROM Aktif hari ketiga kelompok Intervensi dan Kelompok Kontrol dengan Menggunakan Uji MannWhitney

\begin{tabular}{llll}
\hline \multicolumn{1}{c}{ Variabel } & N & Mean Rank & Pvalue \\
\hline Ekstremitas atas & & & \\
$\quad$ Kelompok intervensi & 9 & 12,06 & 0,030 \\
$\quad$ Kelompok Kontrol & 9 & 6,94 & \\
\hline Ekstremitas bawah & & & \\
$\quad$ Kelompok intervensi & 9 & 11,72 & 0,058 \\
$\quad$ Kelompok kontrol & 9 & 7,28 & \\
\hline
\end{tabular}

Hasil analisis dengan menggunakan uji Mann-Whitney mengukur skala kekuatan otot ekstremitas atas antara kelompok intervensi dan kelompok kontrol terdapat perbedaan yang signifikan skala kekuatan otot ekstremitas atas kedua kelompok $(p=0,03)$, sedangkan skala kekuatan otot ekstremitas bawah antara kelompok intervensi dan kelompok kontrol tidak terdapat perbedaan yang signifikan skala kekuatan otot ekstremitas bawah kedua kelompok $(p=0,058)$. Meskipun tidak terdapat perbedaan skala kekuatan otot ekstremitas bawah kedua kelompok tersebut maka akan menunjukkan terjadinya perbedaan rata-rata peringkat skala kekuatan otot ekstremitas bawah dari 11,72 menjadi 7,28. Penelitian ini didukung oleh penelitian (Setyorini \& Setyaningrum 2019) tentang intervensi latihan $R O M$ aktif pada ekstremitas atas terhadap perubahan emosional. Hasil penelitian ini menunjukkan terdapat perbedaan yang bermakna pada kelompok perlakuaan sebelum dan sesudah intervensi latihan $(p=0,003)$, sedangkan pada kelompok kontrol tidak terdapat perbedaan yang bermakna $(p=0,530)$. Menurut peneliti, pada kelompok kontrol ekstremitas atas dan ekstremitas bawah tidak dilakukan latihan $R O M$ aktif tetapi hasil nilai rata-rata peringkat juga terjadi perbedaan skala kekuatan otot pada ekstremitas atas dan bawah, hal ini disebabkan karena pada kelompok kontrol tidak dibatasi untuk melakukan kegiatan sehari-hari, mereka bisa melakukan aktifitas lainnya dan bisa juga melakukan latihan $R O M$ atau olahraga yang lainnya tetapi tidak sesuai dengan prosedur latihan $R O M$ aktif yang diberikan pada kelompok intervensi.

\section{KESIMPULAN}

Karakteristik lansia di Panti Tresna Werdha Teratai KM. 6 Palembang mayoritas berusia elderly atau berumur 6074 tahun $(55,5 \%)$, berjenis kelamin lakilaki $(61,1 \%)$, serta mempunyai riwayat penyakit asam urat $(33,3 \%)$ dan hipertensi $(33,3 \%)$. Terdapat perbedaan skala kekuatan otot ekstremitas atas antara hasil pengukuran pretest, posttest 1 , posttest 2 , dan posttest 3 pada kelompok intervensi $(p=0,001)$ dan terdapat perbedaan kekuatan otot ekstremitas bawah pretest, posttest 1 , posttest 2 , dan posttest 3 pada 
kelompok intervensi $(p=0,008)$. Terdapat perbedaan kekuatan otot ekstremitas atas pada kelompok intervensi dan kelompok kontrol $(p=0,03)$, dan tidak terdapat perbedaan kekuatan otot ekstremitas bawah pada kelompok intervensi dan kelompok kontrol $(p=0,058)$

\section{SARAN}

Bagi lanjut usia yang tinggal di Panti Tresna Werdha Tertai KM. 6 Palembang dapat melatih kekuatan otot dengan latihan ROM aktif secara teratur, sehingga dapat mengurangi keterbatasan gerak dan membantu meningkatkan kekuatan otot dan aktivitas sehari-hari lansia dapat terpenuhi. Petugas panti dapat melakukan latihan ROM aktif dan memprogramkan secara rutin. Bagi akademik dapat digunakan sebagai tambahan untuk memperkaya pengetahuan dan keperluan refrensi ilmu keperawatan gerontik, dan diharapkan dapat diterapkan di laboratorium gerontik untuk keperawatan komunitas khususnya pada lansia. Bagi peneliti selanjutnya harus memodifikasi dengan latihan rentang gerak aktif yang lain seperti senam ergonomik dan alat untuk mengukur uji kekuatan otot nya bisa menggunakan alat dynamometer.

\section{DAFTAR PUSTAKA}

Andriani, H., Indriati, P.\& S., 2013. Pengaruh Range Of Motion (ROM) Aktif Terhadap Kekuatan Otot Ekstremitaas Atas Lansia. (JIKK), Jurnal Keperawatan dan Kebidanan, 1(8), pp.470-476.

Hardika, B.D. \& Pranata, L., 2019. Pendampingan senam lansia dalam meningkatkan kualitas tidur. Journal of Character education society, 2(2), pp.34-38. Available at: http://journal.ummat.ac.id/index.php/ JCES/article/view/1474.

Imron, J. \& Asih, S.W., 2015. Pengaruh Latihan ROM Aktif Terhadap
Keaktifan Fisik Pada Lansia Di Dusun Karang Templek Desa Andongsari Kecamatan Ambulu Kabupaten Jember. Jurnal Edu Health, 5(1), p.51-59.

Kirnanoro, H.\& M., 2017. Anatomi Fisiologi, yogyakarta: Pustaka Baru Press.

Kisner, C. \& Colby, L.A., 2016. Terapi Latihan: Dasar dan Teknik. 6 ed, jakarta: EGC.

Kneale, J. \& Davis, P., 2011. Keperawatan Ortopeedik \& Trauma. 2 ed, jakarta: EGC.

Kowalak, j. p, 2011. Buku Ajar Patofisiologi, jakarta: EGC.

Lilik Pranata, Dheni koerniawan, N. elisabeth D., 2019a. EFEKTIFITAS ROM TERHADAP GERAK RENTANG SENDI LANSIA. Proceeding Seminar Nasional Keperawatan, 5(1), pp.110-117. Available at: http://conference.unsri.ac.id/index.ph $\mathrm{p} / \mathrm{SNK} /$ article/viewFile/1636/880.

Lilik Pranata, Dheni koerniawan, N. elisabeth D., 2019b. Efektivitas ROM Terhadap Perubahan Aktivitas Lansia. In Prosiding seminar Nasional dan Diseminasi Hasil Penelitian. Palembang: Universitas Katolik Musi Charitas, p. 25.

Mudrikhah, S., 2015. Pengaruh Latihan ROM Aktif Terhadap Kekuatan Otot Pada Pasien Stroke Dengan Penurunan Kesadaran Di Ruang HCU IGD RSUD Dr. Moewardi Di Surakarta Tahun 2012. Kosala, 3(1), pp.43-49.

Muhith, A. \& Siyoto, S., 2016. Pendidikan Keperawatan Gerontik, yogyakarta: Andi Offset. 
Padila, 2013. Buku Ajar Keperawatan Gerontik, yogyakarta: Nuha Medika.

Pinontoan, P. M., Marunduh, S.R.\& W., 2015. Gambaran Kekuatan Otot Pada Lansia Di BPLU Senja Cerah Paniki Bawah. Jurnal e-Biomedik, 3(1).

RI, K.K., 2017. Analisis Lansia Di Indonesia,

Ridha, M. R. \& Putri, M.E., 2015. Pengaruh Latihan ROM Aktif Terhadap Kekuatan Otot Ekstremitas Bawah Pada Lansia Dengan Osteoarthritis Di Wilayah Kerja Puskesmas Koni Kota Jambi. Jurnal Akademika Baiturrahim, 4(2), pp.4552.

Santoso, H. \& Ismail, A., 2009. Memahami Krisis Lanjut Usia: Uraian Medis dan PedagogisPastoral, jakarta: Gunung Mulia.

Setyorini, A. \& Setyaningrum, N., 2019. Pengaruh Latihan Range of Motion (Rom) Aktif Assitif Terhadap Rentang Gerak Sendi Pada Lansia Yang Mengalami Immobilisasi Fisik. Surya Medika: Jurnal Ilmiah Ilmu Keperawatan dan Ilmu Kesehatan Masyarakat, 13(2), pp.77-84.

Sukis, Syamsulhuda \& Husodo, B.T., 2016. Faktor-Faktor Yang Berhubungan Dengan Terapi Konservatif ROM pada Lansia Penderita Nyeri Sendi Unit pelayanan Sosial Lanjut usia "Wening Wardoyo Unggaran." Jurnal Kesehatan Masyarakat, 4(2), pp.228-234.

Widiarti, 2016. Buku Ajar Pengukuran Dan Pemeriksaan Fisioterapi. $1 \mathrm{ed}$, yogyakarta: Deepublis.

Zhou, Z., Zhenga, L., Wei, D., Ye, M., \& Li, X., 2013. Muscular Strength Measurements Indicate Bone Mineral
Density Loss In Postmenopausal Women. Zhou, Z., Zhenga, L., Wei, D., Ye, M., \& Li, X. 2013. Muscular Strength Measurements Indicate Bone Mineral Density Loss In Postmenopausal Women., 8. 